\title{
Marriage with Two Women at Once According to Marriage Law and the Compilation of Islamic Law
}

\author{
Sumayyah Muflihah ${ }^{1} \quad$ Aris Munandar $^{2} \quad$ Any Suryani Hamzah ${ }^{2}$ \\ 1.Master of Notary Study Program, Faculty of Law, University of Mataram, Indonesia \\ 2.Lecturer of Master of Notary Study Program, Faculty of Law, University of Mataram, Indonesia
}

\begin{abstract}
Marriage when viewed from its type has a lot of diversity, in Indonesia, marriages that are recognized in the Marriage Law and the Compilation of Islamic Law are monogamous marriages and polygamous marriages. In Lembar Village, West Lombok Regency, NTB Province, it was found the practice of marriage between a man with the initials SB and two women. This study aims to determine whether marriage with two women at once contradicts or not with the Marriage Law and the Compilation of Islamic Law and to find out the legal consequences of the marriage using normative legal research with a statutory, conceptual, and historical approach. Descriptive analysis, data collection techniques by means of library research and documentation. The results showed that: 1) Marriage with two women at the same time is contrary to Article 3 paragraph 1 of the Marriage Law; 2) The legal consequences of marriage with two women at the same time are classified into 3 (three) legal consequences, including: a) The legal status of marriage with the first wife is legally and legally valid \& the legal status of marriage with the second wife is punished as an underhand marriage because the conditions are not met; b) The legal consequences for the child of the first wife is to get legal certainty as a legitimate child, while children born to the second wife cannot get legal certainty as a legitimate child; c) The legal consequences of husband and wife assets whose marriage is recognized by the state can claim joint property in the event of a divorce. Meanwhile, husband and wife whose marriage is not recognized by the state in the event of a divorce, cannot claim their rights in court.
\end{abstract}

Keywords: Monogamy Principle, Marriage Law, Islamic Law, Polygamy

DOI: $10.7176 / \mathrm{JLPG} / 112-17$

Publication date:August $31^{\text {st }} 2021$

\section{INTRODUCTION}

Marriage according to Islamic law is a sacred agreement between a man and a woman to form a happy family. This agreement contains the meaning of free will between the two parties who promise each other based on the principle of consensual, so that the marriage is expected to last until the end of life. Although it implies the existence of free will, marriage must still pay attention to the legal rules that have been established and validly enforced, because marriage in addition to being a ritual worship is also a legal act. According to Abdul Manan, marriage is a very important thing in the reality of human life. With the existence of domestic marriage, it can be enforced and fostered in accordance with religious norms and the order of community life. ${ }^{1}$

In Islam, someone who is able to marry is recommended to get married immediately. This is as the words of the Prophet Muhammad SAW:

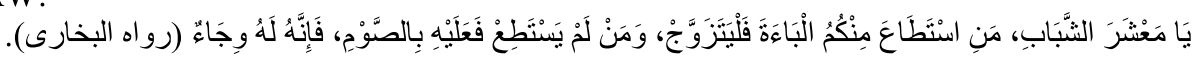

Meaning: "O youths, whoever among you is able to marry, indeed marriage prevents sight and protects the genitals, and whoever is not able to marry, it is obligatory for you to fast. Indeed fasting can prevent lust for you." (HR. Muslim).

The marriage when viewed from its type has a lot of diversity, but in Indonesia marriages that are recognized in the Marriage Law and the Compilation of Islamic Law are monogamous marriages and polygamous marriages, although in principle the law is more inclined to monogamous marriages. ${ }^{3}$ However, it is possible for polygamous marriages to be carried out, this is due to several things and must meet the conditions specified in the Marriage Law and the Compilation of Islamic Law.

In practice, carrying out polygamous marriages is not easy, this is because there are many requirements that must be met by a husband before committing to polygamy. Islam provides very strict conditions if you want to carry out a polygamous marriage, which must be fair, if you can't afford it then this is forbidden and the number of wives that are allowed to be married is a maximum of four people, with a note that if only three wives can fulfill it, then forbidden for him to marry four wives. Polygamy is allowed on the condition that the husband has

\footnotetext{
${ }^{1}$ Abdul Manan, Aneka Masalah Hukum Perdata Islam di Indonesia, Kencana, Jakarta, 2016, halaman 1.

${ }^{2}$ Abi Abdillah Muhammad ibn Isma'il al-Bukhari, al-Jāmi’al-Shahih li al-Bukhari, Jilid III, Maktabah Salafiyah, Kairo, 1400 H/1979 M, Hadits Nomor 5065, halaman 354.

${ }^{3}$ Pasal 3 ayat (1) Undang-Undang Nomor 1 Tahun 1974 tentang Perkawinan, "Pada asasnya dalam suatu perkawinan seorang pria hanya boleh mempunyai seorang istri. Seorang wanita hanya boleh mempunyai seorang suami.
} 
the ability to be fair to his wives and is fair, that is, giving each wife their rights. ${ }^{1}$

Not only Islam regulates the issue of polygamy, the government also strictly regulates the terms of polygamy. This is stated in Law no. 1 of 1974 Jo Law no. 16 of 2019, Government Regulation No. 9 of 1975 concerning the Implementation of Law no. 1 of 1974 concerning Marriage and in the Compilation of Islamic Law (KHI). The rules of polygamy in Law no. 1 of 1974 contained in Articles 3, 4, and 5, while in Government Regulation no. 9 of 1975 is contained in Chapter VIII (Having More Than One Wife) Articles 40, 41, 42, 43, and 44. As for the Compilation of Islamic Law, the rules for polygamy are contained in Chapter IX Articles 55, 56, 57,58 and 59.

Based on the above laws and regulations, having more than one wife must have permission from the religious court and meet the following requirements: (1) the wife cannot carry out her obligations as a wife, (2) the wife has a disability or an incurable disease; and (3) the wife cannot bear children. Due to the polygamy procedure which is considered very difficult and the lack of awareness of the importance of the meaning of a marriage, there are many deviations in society.

The existence of these deviations is caused by norms prevailing in society that have long been rooted since Islam developed. So that applicable Islamic law can be divided into two forms; a) Islamic law that has juridical form, which is part of Islamic law that regulates human relations in society called muamalah, b) normative Islamic law that is part of Islamic law that has sanctions between social equivalents. Its implementation depends on the strength and weakness of the Muslim community's awareness of the normative norms of Islamic law. ${ }^{2} \mathrm{~A}$ fact like this is not easy to get rid of so that not a few irregularities are found in the law of marriage/polygamy.

In Lembar Village, West Lombok Regency, West Nusa Tenggara Province, it was found the practice of marriage between a man with the initials SB and two women. This marriage is very horrendous society. The furore occurred because SB had married two women at the same time. In the video that was widely spread on social media, SB took turns shaking the hand of HY's older brother and HW's second wife's father. While shaking hands, SB made a solemn promise to build a household with a dowry of IDR 2,000,000 (two million rupiah).

The marriage of a man with two women at the same time (consecutive consent) according to Islamic law can be categorized as polygamy. However, legally positive (the Marriage Law) the practice of marriage requires an in-depth study to determine whether the SB marriage is polygamous or not. From these problems, researchers are interested in conducting a more in-depth study of the legal status of the marriage based on the Marriage Law and the Compilation of Islamic Law. This study is implemented in the form of a scientific paper in the form of a thesis with the title "Marriage with Two Women at Once According to the Marriage Law and the Compilation of Islamic Law.

\section{RESEARCH METHOD}

This study is a normative legal research with a statutory, conceptual, and historical approach. Descriptive analysis, data collection techniques carried out by means of library research and documentation. The study aims to determine whether marriage with two women at once contradicts or not with the Marriage Law and the Compilation of Islamic Law and to find out the legal consequences of the marriage.

\section{DISCUSSION}

\section{A. The Legality of Marriage with Two Women at once, according to Marriage Law and The Compilation of Islamic Law}

1. Provisions for more than One Wife (Polygamy) in the Marriage Law and the Compilation of Islamic Law

For a person who will undergo polygamy according to Islam, the main requirement is to be able to act fairly between his wives. Between wives who have the same rights as other wives, both those that are non-material in nature, such as sharing the time to spend the night and having fun, as well as those that are material in the form of providing a living, clothing, and a place to stay. Also everything that is material in nature without distinguishing between rich and poor wives, who come from high and low descendants. ${ }^{3}$ If someone are unable or fearful that he will not be able to do justice, then it is better to marry only one woman. The justice that is demanded is in external matters that can be done by humans, not fair in matters of love and affection. Because love and affection or the like cannot be controlled and controlled by humans, because this problem is beyond one's ability.

Getting the approval of the first wife is a very prioritized thing, because openness must exist in a husband and wife relationship, if a husband wants to marry his wife, he must first get permission from the first wife, in order to get her approval and not to hurt the wife to be married. The terms of polygamy according to the law

\footnotetext{
${ }^{1}$ Irman Noorhafitudin Dimyati, Membangun Ketahanan Keluarga, PT. Remaja Rosdakarya, Bandung, 2017, halaman 103.

2 Juhaya S. Praja, Hukum Islam di Indonesia Pemikiran dan Praktik, PT. Rosdakarya, Bandung, 2012, halaman 17.

${ }^{3}$ Sayyid Sabiq, Fiqh al-Sunah, Jilid II, Muassasah al-Risalah, Beirut, 1426 H/2005 M, halaman 15.
} 
used by the court as a source of law are contained in Law no. 1 of 1974 Jo Law no. 16 of 2019 concerning Marriage in articles 3, 4, and 5 and in Government Regulation no. 9 of 1975 articles 40, 41, 42, 43 which have been explained in the previous chapter. According to the existing legislation in Indonesia, a husband may practice polygamy as long as he fulfills certain conditions that have been stipulated in Law no. 1 of 1974 Jo Law no. 16 of 2019 concerning Marriage. These conditions are contained in Article 3 which explains:

1. Basically a man can only have one wife. A woman can only have one husband.

2. The court may give permission to a husband to have more than one wife if the parties concerned want. ${ }^{1}$

Basically marriage in Indonesia adheres to the principle of monogamy. This is clearly stated in Article 3 paragraph (1) of Law no. 1 of 1974 Jo Law no. 16 of 2019 concerning Marriage which explains that "Basically in a marriage a man may only have one wife. A woman can only have a husband." The rule in this article is in line with the text of Article 27 of the Civil Code (BW) which states that "At the same time a man is only allowed to have one woman as his wife, a woman only one man as her husband". ${ }^{2}$ The Civil Code (BW) adheres to the principle of closed monogamy. Although polygamy is permitted by law, the severity of the requirements that must be followed implies that the implementation of polygamy in the Religious Courts adheres to the principle of closing an open door, meaning that the door to polygamy is not opened if it is not necessary and only in certain cases or circumstances the door is opened.

Regarding the procedure for a husband who will do polygamy, it is also regulated in Government Regulation no. 9 of 1975 articles 40, 41, 42, and 43 which describe a husband who wants to practice polygamy. It explains that if a husband wants to practice polygamy, the husband must first file a case with the court, then the court will re-examine the files of a husband who wants to do polygamy.

The provisions of the Compilation of Islamic Law (KHI) regarding polygamy are not much different from the Marriage Law. It is just that in the Compilation of Islamic Law it is explained that a man with more than one wife is given a restriction, namely a man may not have more than four wives. In addition, the main requirement for a man to have more than one wife is that the man must be able to treat his wives and children fairly. ${ }^{3}$ According to the Compilation of Islamic Law, husbands who wish to have more than one wife must obtain permission from the Religious Courts. As required in the Marriage Law, according to Article 57 of the KHI, the Religious Courts only give permission to a husband who will take more than one wife if: (a) the wife is unable to carry out her obligations as a wife; (b) the wife has a disability or an incurable disease; (c) the wife cannot bear children. ${ }^{4}$

In addition to the things above, in applying for more than one wife, a husband must fulfill the requirements as stated in Article 5 paragraph (1) of the Marriage Law: (a) the consent of the wife/wives; (b) there is certainty that the husband is able to provide for the necessities of life for his wives and children. ${ }^{5}$ Article 58 of the Compilation of Islamic Law also refers to Article 41 letter b of Government Regulation no. 9 of 1975, which states that the wife's or wives' consent can be given in writing or orally, but even if there has been written consent, this agreement is confirmed by the wife's verbal consent in a religious court session. ${ }^{6}$

Based on the explanation above, the researcher sees that the concept of polygamy in Indonesia has been regulated with a strong legal basis. In Law no. 1 of 1974 Jo Law no. 16 of 2019 concerning Marriage essentially adheres to the principle of monogamy, but allows polygamy to be carried out. Government Regulation No. 9 of 1975 concerning the Implementation of Law no. 1 of 1974 regulates polygamy procedures in general, while Government Regulation no. 10 of 1983 Jo Government Regulation no. 45 of 1990 and Circular No. 08/SE/1983 and Circular No. 48/SE/1990 specifically regulates polygamy permits for civil servants. In addition, Presidential Instruction No. 1 of 1991 concerning the Compilation of Islamic Law applies specifically to the Muslim community.

\section{Marital Status with Two Women at once according to the Marriage Act and the Compilation of Islamic Law}

Marriage must be based on Belief in the one and only God. The validity of a marriage must be in accordance with the religious law of each prospective husband and prospective wife. ${ }^{7}$ By adhering to the principle of civil marriage, Law no. 1 of 1974 Jo Law no. 16 of 2019 concerning Marriage, also includes a juridical element, namely that carrying out a marriage must meet the requirements determined by law. ${ }^{8}$ Islam determines the validity of the marriage contract if: (1) the pillars of marriage are fulfilled, (2) the conditions of marriage are met,

\footnotetext{
${ }^{1}$ Anonymous, Law of the Republic of Indonesia Number 1 of 1974 concerning Marriage \& Compilation of Islamic Law, Citra Umbara, Bandung, 2012, page 2.

${ }^{2}$ Hilman Hadikusuma, Hukum Perkawinan Indonesia Menurut Perundang-Undangan, Hukum Adat, Hukum Agama, Mandar Maju, Bandung, 2015, halaman 34 .

${ }^{3}$ Pasal 55 Kompilasi Hukum Islam.

${ }^{4}$ Anonymous, Op. Cit, page 339.

${ }^{5}$ Anonymous, Op. Cit, page 3.

${ }^{6}$ Anonymous, Op. Cit, page 50.

${ }^{7}$ Pasal 2 ayat 1 UU No. 1 Tahun 1974.

${ }^{8}$ Malik Rusdi, Peranan Agama dalam Hukum Perkawinan Indonesia, Universitas Trisakti, 2001, halaman 27.
} 
(3) it does not violate the marriage prohibition determined by the shari'ah.

Based on the explanation above, it shows that the principle of monogamy is used in the marriage agreement, which is basically Law no. 1 of 1974 Jo Law no. 16 of 2019 concerning Marriage adheres to the principle of monogamy in marriage, meaning that a husband may only have one wife and a wife may only have one husband at a time. However, the monogamy principle adopted in the Marriage Law is not absolute, but only directs the formation of monogamous marriages by making it difficult and narrowing the use of polygamous institutions and not completely eliminating the polygamous system.

When viewed in Law no. 1 of 1974 Jo Law no. 16 of 2019 concerning Marriage in Article 4 as described in the sub-chapter above is very complicated and strict. The complexity of the procedure and the strict requirements for polygamy have led to the practice of polygamy outside of marriage registration. In addition, if one considers the reasons for granting permission to practice polygamy, it can be understood that the reason refers to the main purpose of the implementation of marriage, which is to form a happy and eternal household based on God Almighty.

Based on this description, related to SB's marriage with two women at the same time, if analyzed based on the provisions in Article 3 paragraph 1 above, then the marriage is contrary to the laws and regulations. If it refers to the provisions regarding polygamy (more than one wife), SB should first obtain permission from the local religious court. However, if you look at the reality, it is possible that SB will marry two women at the same time to save costs. If the SB applies for a polygamy permit before marrying the two women, it is very likely that the application cannot be accepted. The reason is because the application for a polygamy permit was submitted by a husband who is still in a marriage bond with his first wife. Meanwhile, SB is not married at all and is not yet bound as husband and wife. This means that SB has not met the requirements to apply for a polygamy permit to the religious court.

The researcher is of the opinion that there are no rules (articles/paragraphs) in the Marriage Law that regulates polygamy permits submitted by someone who is not yet bound by a marital relationship. However, SB's marriage to two women at the same time is against the Marriage Law. The occurrence of the practice of marriage of a man with two women at once or other marriage practices that are contrary to state law, shows that the Marriage Law in Indonesia is not effective in society. There are many factors that cause the Marriage Law to be ineffective. In the theory of legal effectiveness initiated by Soerjono Soekanto, one of the factors of the ineffectiveness of a law is the factor of the community itself.

Based on the provisions of the legislation in force in Indonesia, as described above, it is necessary to clarify and differentiate the marital status of SB with his first wife and second wife. SB's marital status with his first wife (first consent) is legal under religious law and state law, because it has fulfilled the marriage requirements as described above. Meanwhile, SB's marital status with his second wife (second consent) is legal by religious law but not legal by state law. This is because SB's marriage to his second wife (second consent) does not meet the requirements set out in Article 3 paragraph (2), Article 4 paragraph (1) and paragraph (2) of Law no. 1 of 1974 Jo Law no. 16 of 2019 concerning Marriage. Therefore, SB's marriage with his second wife (second consent) is considered an underhand marriage (unregistered marriage) even though it is attended by the Marriage Registrar. Therefore, SB's marriage with a second wife will have legal consequences.

\section{B. Due to the Law of Marriage with Two Women at once, according to Marriage Law and a Compilation} of Islamic Law

\section{Underhand Marriage Relationship (Unregistered Marriage) with Marriage Registration}

Basically the term unregistered marriage is not known in state law. Indonesian Marriage Law only recognizes registered and unregistered marriage terms. Unregistered marriage is a reality, popularized by the Indonesian people to refer to marriages that are not registered before the authorities (Islam in the KUA and non-Islam in the Civil Registry) even though in its development there are often deviations in the marriage process (some are according to religious provisions and some do not comply with the law condition).

In relation to the registration of marriages (which are regulated by the state), for example, it is stipulated that registration is a legal requirement for marriage. This rule is considered contrary to Islamic teachings which consider marriage as a very sacred bond and full of religious nuances. In the process, other legal values and traditions that are also informally present in society must be abandoned or adapted to the principles of state law. In this case it was found that the codification of marriage law through the stipulation of Law no. 1 of 1974 Jo Law no. 16 of 2019 concerning Marriage has a negative effect on the role of Islamic marriage law. ${ }^{1}$

Marriage registration regulations, as stated in Law no. 22 of 1946 is still maintained by the Marriage Law which states that a marriage is considered valid if it is recorded before the official marriage registrar according to the terms and conditions. This tradition of registering marriages is, of course, a method foreign to Islamic family law. The fuqaha since the early days of Islam have always discussed the issue of the testimony needed for

\footnotetext{
${ }^{1}$ Ratno Lukito, Hukum Sakral dan Hukum Sekuler, Studi Tentang Konflik dan Resolusi dalam Sistem Hukum Indonesia, Pustaka Alvabet,
} Jakarta, 2008, halaman 263 
testimony to the marriage ceremony (solemnization of a marriage), not discussing the need to record the marriage agreement on paper. ${ }^{1}$

In contrast to most non-Muslim scientists who view registration as the legal validity of marriage. Muslim lawyers argue that the tradition of registering marriages only serves as an administrative burden and has no influence on the validity of marriages. In their view, the marriage bond is still valid in the view of Islamic law even though it is not officially registered at the government office. The tradition imposed by the government with the traditions of the Muslim community regarding the recording is only for the sake of complying with the demands of the state administration and not religious demands. ${ }^{2}$ Islamic jurists agree that unregistered marriages carried out by the Indonesian people as long as they meet the requirements and pillars of Islamic marriage are legal. This is also confirmed by the issuance of the MUI fatwa which states that unregistered marriages are valid as long as the conditions and pillars of marriage have been fulfilled, although it is still recommended that they be recorded through state institutions. That marriage registration is not included in the conditions and pillars of marriage is proof, this discussion is not found in conventional fiqh books.

Bagir Manan, former chairman of the Supreme Court said Law no. 1/1974 stipulates two different principles of legality as the basis for carrying out a marriage, namely the legal basis of a marriage and the conditions of marriage. This issue has become a source of commotion about marriages being recorded and not being recorded or because other conditions are not met. Because every legal relationship that is carried out in accordance with legal requirements will give birth to legal relationships and legal consequences. ${ }^{3}$ In relation to registration of marriage, it is not a condition of marriage. Recording serves to ensure legal order.

Muchsin (Supreme Judge) stated that the provisions for registration of marriages are not equal to the legal provisions for the validity of marriages, so the legal consequences that arise are also different. Meanwhile, the Chief Justice of the Constitutional Court, Mahfud. MD, emphasized that regarding the implementation of religious teachings by its adherents, it is the state's obligation to protect it. The state cannot require the enactment of certain religious laws, but the state is obliged to serve and protect legally for those who want to carry out their religious teachings with their own awareness. Siri marriages (unregistered marriages) do not violate the constitution because they are carried out based on religious beliefs which are protected by the 1945 Constitution. $^{4}$

A different opinion was expressed by Yahya Harahap, that underhand marriage is not legal according to the law or according to Islamic law. ${ }^{5}$ In the author's opinion, marriage registration is important, but to declare a marriage without registration to be invalid according to Islamic law, further explanation should be given to what is meant by Islamic law. It is clear that what Yahya Harahap meant was not shari'ah (al-Qur'an and as-Sunnah) but the result of understanding and developing shari'ah which has been stated in the laws and regulations in force in Indonesia.

Based on this description, in the opinion of the researcher, sociologically-historically, the implementation of siri marriages, which in Indonesia is synonymous with unregistered marriages, has been carried out from generation to generation by both the Muslim community who adhere to their religious teachings and the general public since the days before independence. Even the community, especially the Muslims, was very against the discussion of the Marriage Bill until it went tough even though Law no. 1 of 1974 concerning Marriage (UUP). Starting from here, the controversy regarding unregistered marriages (which are not registered) continues to emerge along with that several articles in the UUUP are also considered a violation of Islamic teachings. Thus, there are two groups: the first group is pro-unregistered marriage and thus rejects several articles in the UUUP including Article 2 paragraph 2. The second group opposes unregistered marriage and thus accepts all the articles in the UUP. These two groups are still having disagreements with regards to unregistered marriage and marriage registration.

Based on this historical background, it can be seen that the state's efforts to regulate unregistered marriages through marriage registration are regulated through state law so that the Marriage Law was born, regardless of the pros and cons. Article 2, paragraph 1 and paragraph 2 of the Marriage Law are the triggers for the controversy over unregistered marriages, which are legal in religion and belief but are not registered through registration institutions (KUA for Muslims and Civil Registry for non-Muslims). In the opinion of the researcher, unregistered marriage is legal as long as it has fulfilled the requirements and pillars, as well as marriage with two women at the same time which is practiced by $\mathrm{SB}$, the marriage is legal under religious law, but contradicts and is not recognized by state law. However, Marriages that are not registered according to the UUUP are not constitutional violations but are only administrative violations, of course, the loss lies with the perpetrators of

\footnotetext{
${ }^{1}$ Ibid., pages 264-265.

${ }^{2}$ Ratno Lukito, Op. Cit., page 267.

"Problematika Hukum Kelurga dalam Sistem Hukum Nasional; Antara Realitas dan Kepastian Hukum, Jakarta,1 Agustus 2009, http://www.badilag.net.

${ }^{4}$ Ibid.

5 "Between Shari'a and State Law", Ummat No. 3 Th. I, August 1995, page 26.
} 
unregistered marriages with all the consequences. Because only marriages that are carried out and recorded by the Marriage Registrar are recognized, especially in terms of population administration.

\section{Legal Consequences of Marriage with Two Women at once according to the Marriage Law and the Compilation of Islamic Law}

In the opinion of the researcher, in Islamic law there is no distinction between the consequences of a marriage, as long as the marriage has met the stipulated conditions so that the marriage is valid. The difference lies in whether the marriage is valid (qualifies and pillars) or invalid (does not meet the requirements and pillars). The negative effect that arises from unregistered marriages is a conflict of interest between the perpetrators of unregistered marriages who do not want to register their marriages on the one hand and the interests of the state to regulate population administration on the other hand so that marriages that are not registered are not recognized by the state.

The legal consequences of underhanded marriages, even though they are legally or religiously considered valid, are marriages that are carried out outside the supervision of the Marriage Registrar, or as in the case of SB's marriage with his second wife (second consent) even though it is attended by the Marriage Registrar, but because of conditions - the conditions of the marriage have not been fulfilled by law, then the marriage does not have permanent legal force and is considered invalid in the eyes of state law. The legal consequences of the marriage have a very detrimental impact on the wife (SB's second wife) and women in general, both legally and socially, as well as for the children who are born.

By law, women who are married in a siri marriages are not considered legal wives. In other words, the marriage is considered invalid. Therefore, the Siri wife is not entitled to a living and her husband's inheritance if the husband dies. Siri's wife is not entitled to this property in the event of a divorce. Siri's wife is not entitled to a wife's allowance and pension allowance from her husband, because her name is not registered in the husband's office. Meanwhile, socially, a siri wife will find it difficult to socialize because women who do unregistered marriages are often considered by the community to live in the same house with men without marital bound (aka live together without being married) in fact many are considered as mistresses. As a result, it will reduce their civil rights as citizens. They are vulnerable to being manipulated by irresponsible men because they do not have the legal power to sue, are easily neglected, are not provided with sufficient income and there is no certainty of status from their husbands, because unregistered marriages are not recognized by law. Another social impact, usually an unregistered marriage will be judged by the community as a marriage that is not ideal and does not create a harmonious household atmosphere. Because unregistered marriages or siri marriages are unknown and not recognized in state law, they do not have rights in terms of legal protection for the marriages they are undergoing. The rights of a husband or wife can only be protected by law after having authentic evidence about their marriage.

The stigma of illegitimate children in the Indonesia legal for children born from extramarital relations or illegitimate marriages has clashed the relationship of Islamic law with state law in terms of recognizing children born from unregistered marriages. This can be seen from the application for a birth certificate submitted to the Civil Registry Office. If you cannot show the marriage certificate of the child's parents, then the child's birth certificate is considered an illegitimate child, the name of the biological father is not written and only the birth mother is written. Information in the form of status as a child out of wedlock and the absence of the father's name will have a very deep social and psychological impact on the child and his mother. A further consequence of unregistered marriages is that children born from such marriages are not entitled to demand a living, education fees or inheritance from their father.

In the context of the legal system of marriage, legal protection by the state (government) for the parties involved in marriage, especially against women as wives, can only be done if the marriage is carried out consciously in accordance with Law no. 1 of 1974 Jo Law no. 16 of 2019 concerning Marriage, one of the conditions is that the marriage is carried out by being registered in accordance with the applicable laws and regulations.

Further consequences, for marriages that are carried out without being registered, the state cannot provide legal protection regarding marital status, marital property, inheritance, and other rights arising from a marriage, because to prove the existence of women's rights (wife) must be proven. First, there is a marriage between a woman (wife) and her husband.

\section{Legal Efforts for Marriage With Two Women At Once To Get The Legality Of Marriage}

If an underhand marriage has already occurred, as is the case with SB's marriage with two women at the same time, then the efforts that can be made to make the underhand marriage legal according to national marriage law are:

1. Marriage Isbat

The essence of marriage isbat is a marriage that was originally not registered to be registered and legalized by the state and has legal force. Marriage registration is an effort that aims to create order in people's lives. The point is that if at any time the marriage certificate is needed it is used as authentic evidence. 
2. Remarriage

a. In fiqh terms, remarriage is termed tajdidun nikah. According to the language, tajdid is renewal, comes from the word jaddada-yujaddidu which means to renew. ${ }^{1}$ prestige). ${ }^{2}$

Remarriage is done like a marriage according to Islam (tajdid). This tajdid is not because it considers the first marriage to be illegitimate, however, tajdid is done to complete the shortcomings that exist in the first marriage (siri). However, marriage must be accompanied by a marriage registration by an authorized official (KUA). Marriage registration is important so that there is clarity of status for husband and wife marriages. However, if there are already children, the status of children born in a (previous) unregistered marriage will still be considered as a child out of wedlock, because remarriage does not apply retroactively to the status of children born before the re-marriage takes place. Therefore, in a birth certificate, a child born before remarriage remains as an illegitimate child, on the other hand, a child born after remarriage has the status as a legitimate child born in a marriage.

\section{CONCLUSION}

Marriage with two women at once is contrary to Article 3 paragraph 1 of the Marriage Law (Law No. 1 of 1974 in conjunction with Law No. 16 of 2019 concerning Marriage), because in principle a man may only have one wife (principle of monogamy). ). In addition, the marriage is also contrary to Article 4 paragraph 1 of the Marriage Law and Article 56 of the Compilation of Islamic Law, because if a husband marries more than one wife, he must first obtain permission from the religious court. Meanwhile, the marriage took place without permission from the religious court.

Legal consequences arising from marriage with two women at once are classified into 3 (three) legal consequences, including:

a. The legal consequences of marital status are divided into two legal statuses. First, the legal status of marriage with the first wife (first consent) is considered valid under religious law and state law because the conditions and pillars of marriage have been fulfilled based on religious law and state law (Marriage Law and Compilation of Islamic Law) so that they are entitled to a marriage certificate. Second, the legal status of marriage with a second wife (second consent) is punished as an underhand marriage because the conditions for marriage with more than one wife (polygamy) are not met, namely there is no permission from the religious court and the first wife to practice polygamy, so there is no entitled to a marriage certificate.

b. The legal consequences for the child of the first wife whose marriage is recognized by religion and state law is to get legal certainty as a legitimate child so that they can take care of birth certificates and other population documents, and are entitled to inherit from both parents. As for the legal consequences for the child of the second wife whose legal status of marriage is not recognized by the state (underhand marriage) is not getting legal certainty as a legal child, so they cannot take care of birth certificates and other population documents. According to the law, children born from underhanded marriages cannot inherit from the father's side, but can only inherit from the mother's side. Because children born from underhanded marriages only have a civil relationship with their mother and their mother's family.

c. As a result of the law on property, husband and wife whose marriage is recognized by the state can claim joint property (gono-gini) in the event of a divorce. Meanwhile, husband and wife whose marriage is not recognized by the state in the event of a divorce, they cannot claim their rights in court because their marriage does not have authentic evidence (marriage certificate) so it is not protected by law. Because they do not have a marriage certificate, there is no legal protection for the rights of husband and wife, especially for the wife who is the most disadvantaged, because if there is a problem in marriage, it is very difficult for the wife to obtain her rights, such as the right to a living, the right to benefits, inheritance rights, and the wife's rights to joint property, as well as a number of other rights.

\section{Recommendation}

With this very limited provision and ability, the researcher tries to provide recommendations in the hope that it can be useful for the implementation of the law in society, while the recommendations are:

1. For Government

a. The need for socialization from related parties about the importance of polygamous permits if you want to carry out polygamous marriages so that polygamous marriages can be registered with the Office of Religious Affairs, with the recording of polygamous marriages will cause legal consequences for the wife and children in the marriage so as to create legal certainty in the polygamous marriage.

b. There is a need for law enforcement, especially in Law no. 1 of 1974 Jo Law no. 16 of 2019 concerning

\footnotetext{
${ }^{1}$ Husain Al-Habsyi, Kamus al-Kautsar Lengkap, YAPI, Surabaya, 1997, halaman 43

${ }^{2}$ A. Masduki Machfudh, Bahtsul Masa’il Diniyah, PPSNH, Malang, 2000.
} 
Marriage so that perpetrators of underhand polygamy do not underestimate the existing rules and can

2. For Society create a deterrent effect for perpetrators so as not to cause negative impacts in the future.

a. The public should be more aware and understand the laws that apply in Indonesia, especially regarding the Marriage Law and the Compilation of Islamic Law, and comply with these laws so that a happy and prosperous marriage can be realized.

b. The Muslim community who wants to carry out polygamous marriages must comply with the provisions of the applicable laws, the Compilation of Islamic Law regulates that if they want to carry out polygamous marriages, they must obtain a polygamous permit from the Religious Courts so that polygamous marriages can be registered by the Marriage Registrar, by recording polygamous marriages, the marriage will be valid according to Law no. 1 of 1974 Law no. 16 of 2019 and the Compilation of Islamic Law.

3. For Researchers

It is hoped that the results of this study can be the basis and reference for future research, so that a research product will be found which can later be used as the basis for the development of national marriage law.

\section{REFERENCES}

A. Masduki Machfudh. 2000. Bahtsul Masa'il Diniyah. Malang: PPSNH

Abdul Manan. 2016. Aneka Masalah Hukum Perdata Islam di Indonesia, halaman 1. Jakarta: Kencana

Abi Abdillah Muhammad ibn Isma'il al-Bukhari, al-Jāmi' al-Shahih li al-Bukhari. 1400 H/1979 M. Hadits

Nomor 5065, halaman 354. Jilid III. Kairo: Maktabah Salafiyah

Anonymous, Op. Cit, page 3.

Anonymous, Op. Cit, page 339.

Anonymous, Op. Cit, page 50.

Anonymous. 1995. "Antara Syariat dan Hukum Negara", Ummat No. 3 Th. I, Agustus 1995, halaman 26.

Anonymous. 2012. Undang-Undang RI Nomor 1 Tahun 1974 tentang Perkawinan \& Kompilasi Hukum Islam, halaman 2. Bandung: Citra Umbara

Hilman Hadikusuma. 2015. Hukum Perkawinan Indonesia Menurut Perundang-Undangan, Hukum Adat, Hukum Agama, halaman 34. Bandung: Mandar Maju

Husain Al-Habsyi. 1997. Kamus al-Kautsar Lengkap, halaman 43. Surabaya: YAPI

Ibid., halaman 264-265.

Irman Noorhafitudin Dimyati. 2017. Membangun Ketahanan Keluarga, halaman 103. Bandung: PT. Remaja Rosdakarya

Juhaya S. Praja. 2012. Hukum Islam di Indonesia Pemikiran dan Praktik, halaman 17. Bandung: PT. Rosdakarya

Malik Rusdi. 2001. Peranan Agama dalam Hukum Perkawinan Indonesia, halaman 27. Universitas Trisakti,

Ratno Lukito, Op. Cit., halaman 267.

Ratno Lukito. 2008. Hukum Sakral dan Hukum Sekuler, Studi Tentang Konflik dan Resolusi dalam Sistem Hukum Indonesia, halaman 263. Jakarta: Pustaka Alvabet

Sayyid Sabiq, Fiqh al-Sunah. 1426 H/2005 M. Jilid II, halaman 15. Beirut: Muassasah al-Risalah

\section{Regulations}

Pasal 2 ayat 1 UU No. 1 Tahun 1974.

Pasal 3 ayat (1) Undang-Undang Nomor 1 Tahun 1974 tentang Perkawinan, "Pada asasnya dalam suatu perkawinan seorang pria hanya boleh mempunyai seorang istri. Seorang wanita hanya boleh mempunyai seorang suami".

Pasal 55 Kompilasi Hukum Islam. 